\title{
Dijital Nesil, Dijital İletişim ve Dijitalleşen (!) Türkçe*
}

Tüba KARAHISAR, Yrd. Doç.Dr., İstanbul Gelişim Üniversitesi GSF, tkarahisar@gelisim.edu.tr

ÖZET Sosyologların kuşaklarl; X,Y,Z olarak bölümlendirmesiyle birlikte aslinda bu bölümlendirmenin iletişim araçlarının etkileşimliliğine göre yapıldığı kanısı giderek güçlenmektedir. Zira Z kuşă̆ı olarak adlandırılan dijital nesil, iletişim kanalı olarak interneti ve akıll telefonları tercih etmeye başlamıştır. Küreselleşme ile birlikte İngilizce, dijital neslin kullandığı iletişim araçlarının başat dili olmuştur. Hızlı olma tutkusu,etkileşimsellik, hayatın diğer alanlarında Z kuşağını hızlı, tez canlı olmaya zorlarken dilde de kendisini hissettirmektedir. Öyle ki yazılan kelimelerden sesli harfler çıkarılmakta, konuşma dilindeki basit kelimeler kısaltılmakta, duygu durumları noktalama işaretlerinden oluşan ifadelerle anlatılmaya çalışılmaktadır. Ayrıca yarı Türkçe yarı Ingilizce yazılan cümlelerin yanı sıra konuşma dilini olduğ gibi yazıya aktarma da Z kuşă̆ı arasında giderek yaygınlaşmakta, hatta düzgün cümle kuranlar azınlıkta kalmaktadır. Bu bağlamda çalışmada yöntem olarak literatür taraması yapılmıştır. Ayrıca, özellikle forum siteleri ve sosyal paylaşım sitelerindeki yazışmalar da incelenmiştir.

Anahtar Kelimeler Z kuşă̆ı, Türkçe'nin bozulması, elektronik iletişim, küreselleşme, sosyal medya.

\section{Digital Generation, Digital Communication And The Digitalized (!) Turkish}

ABSTRACT The generation $X, Y, Z$ division of sociologists reinforces the opinion that this division is done in accordance with the interactivity of communication devices. This is because the digital generation referred to as generation $Z$ has started to prefer the internet and smart phones as a means of communication. The influence of globalization has led English to become the principle language of communication devices used by the digital generation. As the passion for speed compels generation $\mathrm{Z}$ to be fast, impatient in other areas of the interactive life, its influences are also felt on the use of Turkish. Such that vowels are being omitted from words that are written, the simple words in the colloquial language are abbreviated, states of emotion are tried to be explained with expressions consisting of punctuation marks. Also, in addition to the half Turkish, half English sentences, transferring this to writing as in the colloquial language is also gradually spreading amongst generation $Z$, and in fact those forming proper sentences are becoming a minority. In this context, literature scanning method was carried out as a method in this study. The correspondences particularly in online forums and social networking sites have also been analyzed.

Key Words Generation Z, the deformation of theTurkish language, e-communication, globalization, social media.

\footnotetext{
* Bu çalışma 25-26 Nisan 2013 tarihinde Girne Amerikan Üniversitesi tarafından yapılan Yeni Tehditler, Sosyal Medya Çağında İletişim Sempozyumu'nda bildiri olarak sunulmuştur.
} 


\section{Giriş}

İletişim araçları, geçmişten günümüze dek mesafeleri kısaltarak daha kolay haberleşmemize yardımcı olmuştur. Telgraf, telefon, radyo, televizyon ve internet iletişim tarzımızı değiştirirken anlaşmamızı sağlayan ortak dili de (Türkçe) etkilemiştir. Teknolojinin dil üzerindeki tahakkümü son yıllarda giderek artmıştır ve yeni medya bu tahakkümün en çok hissedildiği alandır. Veri, ses, yazı, görüntü, resim ve video gibi farklı öğeleri barındıran yeni medya, dil aşınmasının yaşandığı bir mecradır. Web 1'den Web 2'ye geçilmesiyle etkileşimlilik artmış; sosyal ağlar, gün içinde milyonlarca yorumun yazıldığı alanlar haline gelmiştir. Sosyal medyanın katılımcı, açık, çift yönlü iletişime olanak tanıyan dinamik yapısı gençleri cezbetmekte hatta bağımlılığa da neden olabilmektedir. Sosyal medya, kanaatkâr ve temkinli $X$ kuşağının tersine hıza ve tüketmeye bağımlı $Y$ ve $Z$ kuşağının vazgeçilmez tutkusu haline gelmiştir. Ülkemizde sözlü kültürün, yazılı kültüre olan üstünlüğü, televizyon izleme oranının yüksek olmasına karşın gazete tirajlarının düşüklügüu, uzun yıllardan beri eleştiri konusu olmuştur. Günümüzde de gençler arasındaki sosyal medya bağımlılığı ve sosyal medyadaki Türkçe'nin bozulması tartışılmaktadır. Araştırmada; dil, dil ve düşünce sistemi, dildeki değişmeler, internet ve yeni medyanın dil üzerindeki etkileri, yanlış yazımların ortak dili nasıl bozduğu konuları üzerinde durulacaktır.

\section{Dil ve Kültür}

"Kültür, bir toplumda geçerli olan ve gelenek halinde devam eden, her türlü dil, duygu, düşünce, inanç, sanat ve yaşayış öğelerinin tümüdür. Kültür, hiç kuşkusuz tarihsel bir süreçte oluşmuş ve geçmişten sürüp gelen bir kalıttır ama tümüyle kalıplaşmış değildir. Bu nedenle de yeniden öğrenilip gelecek kuşaklara aktarılması gereken tarihsel ve toplumsal bir kalit demektir" (Turan, 1999, 165).

Dil, kültür ve tarih, birbirini tamamlayan, biri olmadan diğerini açıklamanın mümkün olmadığı, iç içe geçmiş kavramlardır. Tarihte yaşanılan çeşitli siyasi olaylar dili, kültürü tamamıyla etkilemiştir. Humbolt'a göre de dil ve kültür sürekli birbirini etkilemektedir dolayısıyla dilde yaşanan yozlaşma ile kültürel yabancılaşmanın eşzamanlı olması muhtemeldir (Yaman\&Erdoğan, 2007, 238-239).

"Kültür, iletişimle aktarıldığı, iletişimle başlatıldığı için inanç sistemlerimiz ve geleneklerimiz yeni teknolojik sistemle temelden dönüşmüş, zaman içinde daha da fazla dönüşecektir" (Castells, 2003, 441).

Bernstein, bireylerin kullandıkları dili toplumsal hayatlarıyla ilişkilendirmekte ve şöyle bir varsayım öne sürmektedir: Bir toplum ya da kültürde dil kullanımı bireyin dâhil olduğu toplumsal sınıfla bağlantılıdır. Buna göre alt ve orta tabaka üyeleri dili farklı şekilde kullanırlar ayrıca ortak dili algılamaları da birbirinden farklıdır (Gökçe, 2003, 120-121). Örneğin orta sınıftan olan çocuklar alt tabakadaki çocuklara oranla daha betimleyicidir. Çocukların iletişimsel becerilerinin gelişimi sosyal çevresine dayanmaktadır (Lazar, 2001, 76). 
Her toplum kendi şartlarına göre ihtiyaç duyulan kelimeleri yapar ve kullanır. Bir dilin belli bir toplumda ve belli bir zaman dilimindeki kelime hazinesi o toplumun kültürel yaşamı ile ilgilidir. Örneğin tarım kültürünün hâkim olduğu bir toplumdaki kelime çeşidi ile sanayi toplumunun kullandığı kelimeler birbirinden farklıdır. Türkçe'de 'kar' ile ilgili tek kelime varken Eskimolar'da 18 çeşidi vardır. Teknolojide, bilimde, güzel sanatlarda varılan gelişme düzeyi ile kelimelerin çeşitlenmesi arasında bağlantı vardır (Zıllığlu, 2007, 116).

"Yaşayan kültürleri ayakta tutan dildir. O kadar ki, kimi sosyal bilimciler toplum olgusuna ‘dil-kültür sistemi” derler. Tutucu çevreler:

- Kalkınalım, gelişelim ama kültürümüz değişmesin.

- Kültürün değişmesi kaçınılmaz ise hiç olmazsa dilimiz değişmesin diyorlar.

Gelişme ile çağdaşlıktan yana olanlar ise:

- Her değişme gelişme değildir ama gelişmek için kültür değişmesi şarttır.

- Kültür değişince de dilin değişmesi kaçınılmazdır; dil, kültürün aynasıdır.

Görüşünü savunuyorlar. Tarihçi Braudel ise dil kimlik ilişkisini 'kimlik=dildir' şeklinde açılamıştır" (Güvenç, 1996, 259, 263).

Birey öncelikle kendi diliyle düşünür, öğrenir ve yazar. Anadilde yazılmış bir metin ile sonradan öğrenilen yabancı dille yazılmış metin anlaşılabilirlik açısından çok farklıdır (Kabadayı, 2006, 307).

\section{Geçmişten Günümüze Türkçe}

Geniş bir coğrafyada yaşayan ve sürekli hareket halindeki Türkler tarihte pek çok toplumla iletişime geçmiştir. Türkçe şu dillerden etkilenmiştir: Çince, Farsça, Urduca Arapça, Rusça, Ermenice, Macarca, Fince, Romence, Bulgarca, Sırp-Hırvatça, Lehçe, Çekçe, İtalyanca, Arnavutça, Yunanca. Bu diller arasından Çince, Farsça, Arapça ve Rusça daha uzun bir zaman diliminde Türkçe ile yakın temas içinde olmuştur. Din, sanat, bilim, kültür, ticaret, komşuluk, savaş, yöneten-yönetilen ilişkileri vb. konularda çok boyutlu ilişkiler inşa edilmiştir (Yüksekkaya, 2006, 19-20).

“Sapir'e göre dile giren yabancı sözcüklere karşı psikolojik bir direniş söz konusudur. Bu direniş, iki ülke kültürleri arasındaki ilişkilerin yakınlığına bağlı olarak değişik olabilir. Söz gelimi, Almanca İngilizce'ye kıyasla Roma ve Fransız kültür alanlarıyla daha az sıcak ilişkiler içinde olduğundan Latince ve Fransızca'dan daha az sözcük almıştır" (Çakır, 1994, 98).

Türk toplumunun İslam ve Doğu medeniyetlerinin etkisi altında kaldığı yıllar aynı zamanda Türkçenin dışlandığı yıllardır. Selçuklular döneminde Arapça'nın ve Farsça'nın etkisi büyüktür hatta medreselerde öğretim dili Farsçadır (Şamiloğlu, 1999, 160). "1277'de Karamanoğlu Mehmet Bey, 'Şimdengeru hiç gimesne kapıda, divanda, mecliste, seyranda Türk dilinden özge söz söylemesinler' diye ferman yayınlayarak Arapça ve Farsça'yı yasaklamış, Türkçe' yi resmi dil haline getirmiştir. Yunus Emre, o zamanki saray edebiyatı ya 
da saray dili karşısında halkın diliyle konuşmuş, halkı kendi dilinden konuşturmuştur" (Evcen, 1999,121).

Kaşgarlı Mahmut, İslam dünyasına Türkçe'nin yanında Türk kültürünü de öğretmeyi amaçlamıştır. Dil-kültür bütünlügüüü ilk ele alan en eski toplum dilbilimcisidir (Özönder, 2008, 1).

Türk Dili ile ilgili çalışmalar, Cumhuriyet'in dört döneminde incelenir: 1. Dönem (1923-1938 Atatürk Dönemi), 2. Dönem (1939-1950), 3. Dönem (1951- 1980), 4. Dönem (1981'den günümüze) (Sinanoğlu, 2004, 199).

“Atatürk Kültür, Dil ve Tarih Yüksek Kurumu, Anayasamızın 134. maddesi gereğince 2876 sayılı kanunla; Atatürk'ün direktifleriyle 1931 yılında kurulan Türk Tarih Kurumu ve 1932 yılında kurulan Türk Dil Kurumu'na Atatürk Araştırma Merkezi ve Atatürk Kültür Merkezi'nin ilavesiyle kamu tüzel kişiliğine sahip olarak 17.8.1983 tarihinde kurulmuştur.

Bünyesindeki kurumlar: Atatürk Araştırma Merkezi, Türk Dil Kurumu, Türk Tarih Kurumu ve Atatürk Kültür Merkezi'dir" (www.ayk.gov.tr).

“Türk Dil Kurumu, Türk Dili Tetkik Cemiyeti adıyla 12 Temmuz 1932'de Atatürk'ün talimatıyla kurulmuştur. Cemiyetin kurucuları, hepsi de milletvekili ve dönemin tanınmış edebiyatçları olan SâmihRif'at, Ruşen Eşref, Celâl Sahir ve Yakup Kadri'dir. Kurumun ilk başkanı SâmihRif'at'tır. Türk Dili Tetkik Cemiyetinin amacı, 'Türk dilinin öz güzelliğini ve zenginliğini meydana çıarmak, onu yeryüzü dilleri arasında değerine yaraşır yüksekliğe eriştirmek' olarak tespit edilmiştir.

Türk Dil Kurumu başlangıçtan beri çalışmalarını iki ana eksen üzerinde yürütmüştür:

1. Türk dili üzerinde araştırmalar yapmak, yaptırmak;

2. Türk dilinin güncel sorunlarıyla ilgilenerek çözüm yolları bulmak (www.tdk.gov.tr).

\section{Dil, Düşünce ve Dil Sistemi}

Dil ile bağlantılı ilk sistematik görüşler Eski Yunan felsefesinde vardır. Herakleitos, akıl ve sözü (logosu) evrenin ve insanın bilgisinin başat ilkesi olarak kabul ederken metafizik bir görüş geliştirmiş, dil felsefesi ile doğa felsefesinin ayrılmasını sağlamıştır. Ona göre, insanın dünyasında konuşma yetisi her şeyin merkezindedir. Evrenin anlamına ermek için konuşmanın ne anlama geldiğini bilmek gerekir (Z1llığlu, 2007, 114).

Descartes, düşüncenin kelimeden önce doğduğunu ileri sürer fakat dil problemiyle ayrıntılı olarak ilgilenmez. Locke ise Descartes'in 'doğuştan gelen düşünceler' kuramını eleştirir. Çünkü Locke, kelimelerin kökenini dış dünyaya bağlı fikirlerde bulur. Leibniz, kelimelerin ses taklitlerinden doğduğunu savunur (Vardar, 2011a, 27).

Fransız düşünürlerinin çoğu, Condillac, Maupertuis, Rousseau, Condorcet, Turgot, Volney dil ile ilgili sorunlarla yakından ilgilenmişlerdir. Fakat dillerin bölge farklılıklarını göz ardı etmişlerdir (Renan, 2011, 58). 
Umberto Eco, 'Açık Yapıt' adlı eserinde dilin önemli bir öğe olduğunu vurgular. “Tabi olarak dil, insanlar arasında iletişimi sağlamanın temel metodudur. İletişim kurmak için yazılı ve sözel olmayan diye ayırabileceğimiz iki temel metod da vardır. Fakat dil ile iletişim kurmak diğerlerine göre daha baskındır" (Sütçü, 2012, 78-79).

İnsan demek dil, dil demek de toplum demektir. Dil hem toplumdaki bireylerle özdeşleşir hem de toplumun üstünde ve dişında yer alır. Dilin ilk işlevi iletişim kurmaktır ve bireyi toplumsallaştıran, ulusu oluşturan temel öğedir (Vardar, 2011b, 15).

“Mustafa Kemal Atatürk'ün kendi el yazısıyla kaleme almış olduğu 'Vatandaş İçin Medeni Bilgiler'kitabı 'ulus' tanımıyla başlar. Atatürk'e göre, ortak tarihi paylaşan ve ortak geleceği düşleyen insanların oluşturduğu topluluktur, ulus. Bu ortak bilinci oluşturan doğal ve tarihsel olgulardan biri de dil birliğidir" (Külebi, 1999, 68-69).

\section{Dil ve Değişme}

Humboldt'a göre dil bir eser değil faaliyettir. Dil bir eser olsaydı hiçbir şekilde değişmemesi gerekirdi. Oysa dil sürekli değişir, dile ait şekiller eskir, yerlerini yenileri alır. Dil, hiç durmaksızın yenilikler doğuran bir kaynaktır (Üçok, 2004, 74-75). Sadece Latince gibi ölü diller değişmez. Dil değişmeleri, sesler, sözcük anlamları, kullanım şartları, sözdizim kuralları olmak üzere dilin her kademesinde görülebilir. Değişmeler diğer dillerin etkisiyle olabileceği gibi dilin kendi dinamizmi ile de gerçekleşebilir (Huber, 2008, 62-63).

"Hiçbir dilden etkilenmeyen, kelime almayan saf bir dilin varlığından söz edilemez. Dillerin kelime alıntılamaları iki şekilde olabilir: Temelinde öğrenmenin yer aldığı alıntılara bilgi alıntıları denir. Bir de, genellikle bilgi ve öğrenme dışında; siyasi ve iktisadi üstünlük, yönetici-yönetilen ilişkisi, özenti ve modalaşma gibi konularla ilgili alıntılar vardır. Bu tür alıntılara da özenti alıntıları denilmektedir. Dilimizin tarihi dönem içerisinde en fazla etkilendiği dillerin başında Arapça ve Farsça gelmektedir. Türkçeye girmiş batı kökenli yabancı sözcük sayısının ortalama on bine yakın olduğu düşünüldüğünde, bu sözcüklerin \%70'inden fazlasının Fransızca' dan geçen kelimeler olduğu görülür"' (Kabadayı, 2006, 304).

Dilin kullanımı konusunda, bir kesim doğrudan yabancı kelimeleri kullanmayı tercih ederken bir kesim de Türkçe kelimeleri kullanmaya özen göstermektedir. Diğer bir kesim de Öztürkçe kullanmaktan yanadır. Dolayısıyla karşımıza çok geniş bir yelpaze çıkmaktadır. Türkçe olmayan sözcüklerin karşılıklarını bulmak ve bunun kullanımını sağlamak külfetli bir iş olduğu için bundan ıcılmaktadır (www.be.itu.edu.tr/ gulsen.taskin/gulsen_ozturkce.pdf ). Yine de bilişim teknolojisiyle ilgili dilimize kazandırılan terimler şunlardır: Bilgisayar, çevirmeli ağ, çevirmeli bağdaştırıcı, çift tıklamak, donanım sürücüsü, sanal, yazıcı, sohbet odası, tarayıcı, yazılım, sürüm, bellek, sunucu, tasarım vb. (Kabadayı, 2006, 307).

Türk Dil Kurumu bünyesindeki Yabancı Kelimelere Karşıllı Bulma Komisyonu, bin beş yüzün üzerindeki yabancı kelimeye karşılık bularak bu çalışmasını 'Yabancı Kelimelere Karşılıklar' adıyla kitaplaştırmış ve medya kuruluşlarına göndermiştir. Fakat bu çalışma medya kuruluşlarınca dikkate alınmamıştır (Türkçe'deki Bozulma ve Yabancılaşmanın 
Araştırılması, Türkçe'nin Korunması ve Etkin Kullanımı için Alınması Gereken Önlemlerin Belirlenmesi Amacıyla Kurulan [10/365] Esas Numaralı Meclis Araştırması Komisyon Raporu).

\section{İnternet ve Türkçe Kullanımı}

Birinci bölümde ifade edildiği gibi dil aynı zamanda kültürün de aktarıcısıdır. Küreselleşme ile birlikte dil, yazı dili olumsuz anlamda etkilenmiştir. Küresel dünyanın dili İngilizce olarak sunulmuş ve bu durum insanlar tarafından gözü kapalı olarak kabul edilmiştir. Sadece Türkçe değil diğer diller de bu gidişattan etkilenmiştir ve etkilenmektedir (Temur\&Vuruş, 2009, 233). Teknolojik ve ekonomik gelişmeler, jeopolitik gruplaşmalar İngilizce'ye verilen değeri daha da arttırmıştır. Rusya, Orta Asya gibi ülkelerde de İngilizce öğrenimi yaygınlaşmaktadır (www.turkoloji.cu.edu.tr/Genel/18.php ).

Dilin kullanımını doğrudan etkileyen bir başka öğe de medyadır. Televizyon izleme alışkanlığının yüksek olduğu ülkemizde özellikle çocuklar dilin yanlış kullanımı ile karşı karşıya kalmaktadır. Ekrandaki dilbilgisi kurallarına uymayan yazılar çocuklar tarafından fark edilememekte ve doğruymuş gibi algılanmaktadır.

Dil ve yazı birbirinden farklı göstergeler dizgesidir. Yazının varoluş sebebi dili göstermektir. Yazının saygınlığını Saussure şöyle açıklar:

- “Sözcüklerin yazılı görüntüsü sürekli ve sağlam bir şey izlenimi uyandırır; yazıyı, süre içinde dilin birliğini sağlamaya sesten daha elverişli görürüz.

- Bireylerin çoğunda görsel izlenimler işitim izlenimlerinden daha belirgin, daha süreklidir. Yazı görüntüsü sesin yerini alarak kendini benimsetir" (Saussure, 2001, 56$57)$.

Saussure'nin de açıkladığı gibi yazı görüntüsü sesin yerini alır, zihin görüntüyü kaydeder. $\mathrm{Bu}$ durum etkileşimli medya için de geçerlidir. Çocuklar internette gördükleri yanlış yazıların ayrımını yapamadıkları için olumsuz etkilenmektedir.

“2012 yılı Nisan ayında gerçekleştirilen Hanehalkı Bilişim Teknolojileri Kullanım Araştırması sonuçlarına göre Türkiye genelinde hanelerin $\% 47,2$ 'si evden İnternete erişim imkânına sahiptir. Bilgisayar ve İnternet kullanım oranları 16-74 yaş grubundaki erkeklerde $\% 59$ ve $\% 58,1$ iken, kadınlarda $\% 38,5$ ve $\% 37$ 'dir. Bilgisayar ve İnternet kullanım oranlarının en yüksek olduğu yaş grubu \%48,7 ile 16-24 arasındaki yaş grubudur." (www.tuik.gov.tr/PreHaberBultenleri.do?id=10880). TUİK verilerine göre gençler arasında internet kullanım oranı çok yüksektir. İnternet, yazı-ses-görüntünün bir arada olduğu etkileşimli bir medyadır dolayısıyla Türkçe açısından çocukları ve gençleri en çok etkileyebilecek iletişim aracıdır.

Ülkemizde sosyal medya kullanımı da giderek artmaktadır. 2012 Temmuz verilerine göre 7,2 milyon Twitter kullanıcısı vardır (Irak\&Yazıcıoğlu, 2012, 23). Aralık 2012 itibariyle dünyada Facebook kullanıcılarının sayısı 970 milyonu bulmuştur. Amerika Birleşik Devletleri, 168 
milyon kullanıcı ile ilk sırada iken Türkiye 32 milyon kullanıcı ile yedinci sıradadır (www.ab.org.tr/ab13/bildiri/206.pdf).

\section{Sosyal Medya ve Türkçe}

"Sosyal medya" ile Facebook, LinkedIn, Frienster, Hi5, Formspringa, Xing vb. sosyal ağlar; Elektronik sözlükler, forumlar, Youtube, Dailymotion, Google Videos vb. video paylaşım ağları ve Wiki benzeri bilgi paylaşım ağları ve bu ağlardaki Türkçe kullanımı kastedilmektedir.

Günlük konuşmalardaki Türkçe kullanımı ile yazı dilindeki Türkçe kullanımı tabii ki farklılık göstermektedir. İnternette Türkçe'nin öğe dizilişi ve ses uyumu kuralları yoktur. Yeni, farklı bir yapı ve kurallarla karşılaşırız. Bu yeni dil, İngilizce'deki kısaltmalara benzemektedir. Kisaltmalardan oluşan bir dildir. Sanal ortamdaki bu yeni dile Batur ve Avşar "Sanalca" adını vermiştir (www.ab.org.tr/ab06/bildiri/23.doc). İnternet söyleşi dilinin belli pratikleri ve kendine özgü sembolleri vardır. Yılmaz'a göre bu pratikler ihtiyaçtan doğmuştur. Ayrıca bu ifadeler ve simgeler sürekli değişmektedir. Örneğin geçmişte sohbet odalarında kullanılan "asl" (age, sex, location) kısaltma sorusu artık kullanılmamaktadır. Duygu ifade etmek amacı ile kullanılan semboller de yerini animasyonlara terk etmiştir (Yilmaz, ..., 184).

Örneğin özellikle üniversite gençliğinin takip ettiği "Ekşi Sözlük" kendi terminolojisini yaratması bakımından dikkat çekicidir. Ekşi Sözlük'te teknik terimlerden argoya kadar pek çok kelimeye rastlamak mümkündür. "Yok böyle bişii", "ayar vermek", "şukela vermek", hede/hödö" gibi ifadelere sözlükte sıkça geçmektedir (Gürel\&Yakın, 2007, 214). Ekşi Sözlük'te klasik anlamda dilbilgisi kuralları yoktur ve ç, $\breve{g}$, ö, ü, ş gibi harfler genellikle kullanılmamaktadır. Sadece internet sözlüklerinde değil elektronik posta adreslerinde de "ç, ş, ğ, ü" harfleri yazılamamaktadır. Türkçe dışında Fransızca'da da "é, à, ê" harfleri için de aynı durum söz konusudur (Yaman\&Erdoğan, 2007, 239).

İnternet sözlükleri, kimilerince gençlerin özgürce yazdığı bir sözlük olarak görülürken kimilerince de Türkçe'nin katledildiği bir ortamdır. Günümüzde gençlerin bir kısmı yanlış yazdığını bilerek kelimeleri yanlış yazmakta, doğrusunu yazdığında dikkat çekmeyeceğini düşünmektedir. Bazıları ise bilmedikleri için yanlış yazmaktadır. Saussure'nin "Bireylerin çoğunda görsel izlenimler işitim izlenimlerinden daha belirgin, daha süreklidir. Yazı görüntüsü sesin yerini alarak kendini benimsetir" görüşü bu noktada önem kazanmaktadır. Çünkü çocuklar ve gençler yanlış yazımı defalarca göre göre doğrusunu bildikleri halde yanlış yazmaya eğilimli olmaktadır.

“Türkçe” kelimesi Ekşi Sözlük'te arandığında çıkan satırlardan dört tanesi aşağıdaki gibidir: (www.eksisozluk.com/turkce-40008).

1. sondan eklemeli bir dil olma ozelligitasidigindanyabancilara bir fiiilin acilimi kirk saat anlatsan anlamayacaklariepeycene nezih bir dil---ayricamancuca,tunguzca ve mogolcayla ayni dil ailesinde yer alir canim dilim benim 23.02.2000 03:13

(pembe) 
2. turkce; uralaltay dil ailesinin anadolulehcesininistanbulagızıdır. 04.04.2000 13:21

\section{(stranger)}

3. turkolmayipogrenmeamacinda olanlara ba\$arilar dilerim. gercekten zor bir dili su gibi konu\$uyorolmamiz iyi bir \$ey aslinda. 18.12.2000 21:25 22.07.2005 21:01

(nevermind)

4. mükemmel bir estetiğe sahip, yaratcılığ i ile yazmaktan ve yaratmaktan hoşlananlara büyük bir haz veren, gençliğimizin trendleşerek kelimeleri saçma sapan noktalara getirmesi ve bu yüzden gelecek nesilin daha da berbat edeceğini düşündüğüm güzel dilim. 05.06.2003 15:21

(haphazard)

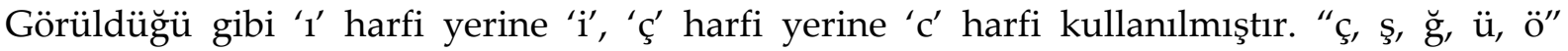
harflerinin kullanımında özensizlik söz konusudur. Takma adlar da çoğunlukla İngilizce kelimelerden seçilmiştir.

Uludağ Sözlük'te "Türkçe" kelimesi yazıldığında çıkan ifadeler aşağıdaki gibidir: Ekşi Sözlük örneğindeki hatalar, Uludağ Sözlükte de tekrarlanmaktadır (www.uludagsozluk.com/).

1. dünyada en çok konuşulan 5.dildir aynı vakitte ..gittikçe yozlaşıyo gerçi ama açmıycam ağzımı şimdilik..

(postsinaptikgolge, 09.05.2006 01:25)

2. türkçe yazıldığı gibi okunmaz, o palavradır. çookçook kurallar vardır. misal: beğin yazar beein okuruz. yumuşak g nin önündeki sesli harf yarım ses ya da bir ses uzar. bunu yaz bi yere unutma hea..

(gecesi, 12.07.2006 01:06)

3. solframe deki sözcüklerin yarısının ingilizce olmasından hatta bu cümledeki frame sözcügünden de anlaşılacağı gibi sözcük kapasitesi aslında hergün artan dil.

(crazyever, 04.11.2006 15:51)

4. yenijenarasyon tarafından, turkche diye kullanilan dil.

(jeam, 07.09.2011 04:45) 


\section{Sosyal Medyadaki Türkçe ve Kısaltmalarla Yazma}

1960'lı yıllardan itibaren gelişmiş ülkelerde yaşanan değişimler toplum bilimcilerce şöyle açılanmıştır: Peter Drucker bu yeni toplumu 'bilgi toplumu', YonejiMasuda 'enformasyon toplumu', Manuel Castells ise 'ağ toplumu' olarak tanımlamıştır (Dolgun, 2005, 103). 19801990 yılları arasında doğan Y Kuşağı ve 1990 yılından sonra doğan Z kuşağını tanımlayan en iyi anahtar sözcük 'hız'dır. Özellikle Z Kuşağı hızın önem kazandığı tüketim toplumunun içine doğmuştur. Hızlı yemek yiyen, hızlı iş değiştiren, hızlı okuyan, nihayetinde hızlı yazan, sabırsız bir kuşak olarak nitelendirilmektedir.

"Konuşma dilinde 'az çaba kuralı" olarak bilinen ve kelimelerin söylenmesinde zamanı azaltmak ve telaffuz kolaylığı sağlamak üzere kelimelerdeki bazı seslerin söylenmemesi ya da değiştirilmesine dayanan uygulamalar, internet ortamında yazılı dil kullanımında da kendini göstermektedir" (Y1lmaz, ..., 182).

Cep telefonlarının ilk kullanılmaya başlandığı dönemlerde, bireyler ekonomik kaygılar nedeniyle kısaltarak yazmayı tercih ederken günümüzde böyle bir kısıt olmadı̆̆ı halde kisaltarak yazmaya devam etmektedirler (Erdoğan, 2012, 242).

Bilgisayar ve internet kullanımının giderek artması özünden kopmuş ve değişmiş kelimeler yığınının ortaya çıkmasında etkili olmuştur. Türkçe harf kullanmada özensizlik, bazı harfleri hiç yazmama, bazı kelimeleri değiştirme şeklinde olmaktadır. Bu çeşit bir yazı şekli yazı geleneğini olumsuz etkilemektedir (Temur\&Vuruş, 2009, 235).

\section{Sosyal Medyada Yapılan Yazım Yanlışları}

- Konuşma Dilinin Yazıya Doğrudan Yansitılması: İstiyosa, gidiom, gelces, şööle, nassın, şimdik, dubidakka vb.

- Kelimeleri Türk Alfabesinde Bulunmayan Harflerle Yazmak: Yoq, qadar, war, eywalla, sex, komplex, ewet vb. (www.turkoloji.cu.edu.tr).

- Sözün Etkisini Arttırmak: Offf, ahhh, selammm, bennn, hayırrrrr, evettttt, hımmmm, heeeeyyyyy vb. (Yaman\&Erdoğan, 2007, 244)

- Ş harfi yerine SH; Ç harfi yerine CH Kullanarak Yazmak: Sheker (şeker), chark (çark), sherbet (şerbet), chilekesh (çilekeş), shekil (şekil),berdush (berduş) vb. (Temur\&Vuruş, 2009, 237).

- Harflerin Yazımındaki Değişiklikler: Yüsünden (yüzünden), tikat (dikkat), bis (biz), güsel (güzel) vb. (Yaman\&Erdoğan, 2007, 242-243).

- Türkçe ve İngilizce Kelimelerin Birlikte Kullanımı: Free takılalım, chokcoolcıkmısın, hafızamdandelete olmuş, format attım anılarıma vb.

- Bazı Kelimeleri Rakamlarla Birlikte Yazmak: Kahve6 yapırum, ömrümü 7 bitirdi, 2leme dushtum, telef10 calıo vb. (Temur\&Vuruş, 2009, 238-239).

- Bağlaçların Yanlış Yazımı: Her ne kadar dinleyemesekte ama dinlices, bisdebi tanısalım, sisde gelin, bizdede 2 bilgisayar var, vb.

- -mi Soru Ekinin Yanlış Yazılması: dimi (Değil mi?), yokmu,sordumu, doğrumu vb. (Yaman\&Erdoğan, 2007, 245).

- İngilizce Kökenli Kelimeler: Byes (güle güle), bradır (erkek kardeş), F.M. (female, male), $4 \mathrm{u}$ (senin için), hand (have a nice day), hru (how areyou), oks (okey), pls (lütfen), p.c. (bilgisayar), tnx (teşekkürler). 
- Kısaltmalar: a.e.o (Allah'a emanet ol), cvp (cevap), i.a (iyi akşamlar), s.s. (seni seviyorum), s.a. (selamünaleyküm) vb.

- Birleşik Fiiller: Nblım (Ne yapalım?), Ne dicem (Ne diyeceğim?), Noldu (Ne oldu?), Npyn (Ne yapiyorsun?) vb.

- Edatlar: Böle (böyle), daa (daha), fln (falan), o kdr (o kadar), öle (öyle), yane (yani) vb.

- Zamirler: Bn (ben), saa (sana), sn (sen), snn (senin) vb. (www.ab.org.tr/ab06/bildiri/23.doc).

- Büyük ve Küçük Harflerin Birlikte Yazılması: SağolBEN KAÇIOM, oyuncuların ardı arkaSI KESİLMIYYR, ben meHmeT vb. (Yaman\&Erdoğan, 2007, 244).

- Türkçeleştirildikleri Halde İngilizce Olarak Kullanılan Kelimeler: Attachment (eklenti), domain name (alan adı), firewall (güvenlik duvarı), freeware (ücretsiz sürüm), newsreader (haber okuma), nick name (takma ad), homepage (ana sayfa), port (kanal) $\mathrm{vb}$.

- -le -la, -mek, -mak Ekleriyle Türkçeleştirmek: Chatleşmek, download etmek, invite yapmak, reply etmek, kliklemek vb. (Kabadayı, 2006, 305).

\section{SONUÇ}

Dil bireysel değil toplumsal bir olgudur. Dolayısıyla toplumu etkileyen her konu dili de etkilemektedir. Bu değişim çoğu zaman din, ticaret, komşuluk, savaş, medya ve teknoloji aracılığıyla olmaktadır.

Dil bir organizma gibidir. Tabii ki değişecek ve gelişecektir. Türkçe, geçmişte Çince, Farsça, Rusça, Ermenice, Fransızca gibi dillerden etkilenmiştir. Teknolojinin dil üzerindeki tahakkümü, internetin hayatımıza girmesiyle daha da etkisini göstermiştir. $Y$ ve $Z$ kuşaklarının bir önceki $X$ kuşağına göre teknolojiye daha hızlı uyum sağlaması ve internetin İngilizce ağırlıklı yapısı, gençleri Türkçe yazmaktan kaçınır hale getirmiştir.

Sosyal medyada yapılan dil yanlışları şunlardır:

- Konuşma dili olduğu gibi yazıya yansıtılmaktadır.

- Sözün etkisini arttırmak için gereksiz harf tekrarları yapılmaktadır.

- Türkçe alfabede bulunmayan Q, W, X harfleri kullanılmaktadır.

- S harfi SH, Ç harfi $\mathrm{CH}$ olarak yazılmakta, ç, ,̆, $, \ddot{o}, s$, ü harflerinin yazımından kaçınılmaktadır.

- Bazı kelimeler rakamlarla birlikte yazılarak kısaltılmaya çalışılmaktadır.

- Bağlaçlar, edatlar, zamirler yanlış yazılmakta ya da kısaltılmaktadır.

- İngilizce kelimeler mastar ekiyle Türkçeleştirilmeye çalışılmaktadır.

- Elektronik sözlüklerde takma adların çoğunluğu İngilizce kelimelerden seçilmiştir.

- Bir taraftan kısaltmalar yaparak yazmak yaygınlaşırken öte taraftan bir harf yerine iki harf yazımı yaygınlaşmaktadır. (S harfi yerine SH gibi). Bu da İngilizce'ye olan özentinin göstergesidir.

Saussure'ın açıkladığı gibi insanların çoğunda görsel izlenimler, işitim izlenimlerinden daha güçlü ve süreklidir. Yazının görüntüsü sese göre kendini daha çok benimsetir. Dolayısıyla 
gerek internette gerekse sosyal medyada yazıların yanlışlığı ve Türkçe'nin yanlış kullanılması hafızada görüntü olarak kaydedilmektedir. İnternet ve sosyal medya, kendine ait bir yazım şekli ve kültürü oluşturmaya devam etmektedir. Bu durum ortak dili olumsuz etkilemektedir. Çünkü okuma yazmayı yeni öğrenen bir çocuk, bilgisayar ekranı karşısında yanlış yazımlarla karşılaşmakta, doğru ve yanlış yazımı ayırt etmekte zorlanmaktadır.

Dil-düşünce sistemi açısından bakıldığında; düşünceyi geliştiren dildir. Sosyal medyada kendini ifade etme ise genellikle sinırlı kelimelerle ve kısaltmalarla olmaktadır. George Orwell'ın 1984 adlı romanında, sisteme itaat eden bireyler yetiştirmek için yeni bir dil oluşturulmuş, fiil sayısı azaltılmış, eş anlamlı kelimeler sözlükten çıkartılmış, dil ve tarih bilinçli bir şekilde yok edilmiştir. Günümüzde de sosyal medyada daha az kelime ve kısaltmalarla kendini ifade etme, dil düşünce bağlantısının zayıflamasına neden olmaktadır.

Dil, kültürün devamını sağlayan, hem özenle korunması hem de gelişmesi için çaba harcanması gereken bir konudur. Dilin bozulması aynı zamanda kültürün de bozulmaya başladığının göstergesidir. Dilin zenginleşmesi için topyekûn bir hareket gerekir. Türkçe bozuluyorsa sadece internette ya da sosyal medyada değil toplumun bütün kurumlarında bozulmaktadır. Ancak internet, hızlı, kolay ve kısa sürede çok kişiye ulaşabildiği için internetin ortak dili erozyona uğratması da o denli hızlı olmaktadır. Türkçe; kitle iletişim araçlarında ve üniversitede doğru kullanılmıyorsa sosyal medyada ya da toplumun diğer kurumlarında da doğru kullanılmıyor demektir. Dolayısıyla Türkçe'nin doğru kullanımında eğitim kurumlarının ve kitle iletişim araçlarının sorumluluğu büyüktür.

\section{Kaynakça}

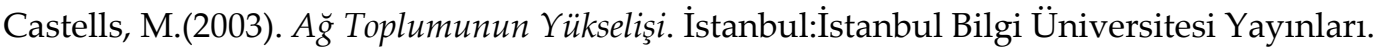

Çakır, M.(1994). Dil Kirlenmesi: Türkçe'de Yabancı Sözcüklerin Kullanımı.Cogito Dergisi, Sayı:2.

Dolgun,U.(2005). Enformasyon Toplumundan Gözetim Toplumuna.Bursa:Ekin Yayınları.

Erdoğan, M.(2012). Yeni Medyada Dil Kullanımı, Fırat Üniversitesi İletişim Fakültesi Medya ve Etik Sempozyumu Bildiriler Kitabı. Ankara:Karınca Yayıncılık.

Evcen, Y.(1999). Dil Bir Ulusun En Güçlü Silahıdır. Radyo ve Televizyon Yayınlarında Türk Dilinin Kullanımı Tebliğler Kitabı.Ankara:TRT Yayınları.

Gökçe, O.(2003). İletişim Bilimine Giriş, İnsanlar arası İlişkilerin Sosyolojik Bir Analizi.Ankara:Turhan Kitabevi.

Gürel, E.,\& Yakın, M.(2007). Ekşi Sözlük: Postmodern Elektronik Kültür. Selçuk Üniversitesi İletişim Dergisi, Sayı:4.

Güvenç, B.(1996). Türk Kimliği: Kültür Tarihinin Kaynakları.İstanbul:Remzi Kitabevi.

Huber, E.(2008). Dilbilime Giriş.İstanbul:Multilingual Yayınları.

Irak, D.,\& Yazıcıŏ̆lu, O.(2012). Türkiye ve Sosyal Medya.İstanbul:Okuyanus Yayınları. 
Kabadayı, O.(2006). A $\breve{g}$ Ortamındaki Türkçeye Genel Bir Bakış. Dil ve Edebiyat Dergisi, Cilt:16, Sayı: 652, Ankara:Türk Dil Kurumu Yayınları.

Külebi, O.(1999). Dilbilim, Dil Bilinci, Dil Yanlışları. Radyo ve Televizyon Yayınlarında Türk Dilinin Kullanımı Tebliğler Kitabı.Ankara:TRT Yayınları.

Lazar, J.(2001). İletişim Bilimi. Ankara: Vadi Yayınları.

Özönder, S.(2008). Kaşgarlı Mahmut Kitabı.Ankara: Kültür ve Turizm Bakanlığı Yayınları.

Renan,E.(2011). Dilin Kökeni Üzerine.İstanbul: Bilge Kültür Sanat Yayınları.

Saussure, F.(2001). Genel Dilbilim Dersleri.İstanbul: Multilingual Yayınları.

Sinanoğlu, O.(2004). "Bye-Bye" Türkçe.İstanbul: Otopsi Yayınları.

Sütçü, C.(2012). Sosyal Medyaya Girmeden Önce Bilinmesi Gerekenler. Yeni Medya ve...,İstanbul: Anahtar Kitaplar.

Şamiloğlu, O.(1999). Eğitim ve İletişim Dili Olarak Türkçe, Radyo ve Televizyon Yayınlarında Türk Dilinin Kullanımı Tebliğler Kitabı.Ankara: TRT Yayınları.

Temur, T.,\& Vuruş, N.(2009). İnternet (Genel Ağ) Ortamında Türkçenin Kullanımına İlişkin Bir Çözümleme. Balıkesir Üniversitesi Sosyal Bilimler Enstitüsü Dergisi, Cilt:12, Sayı:22.

Turan, Ş.(1999). Ortak Kültürün Oluşmasında ve Geliştirilmesinde Dilin Önemi, Radyo ve Televizyon Yayınlarında Türk Dilinin Kullanımı Tebliğler Kitabı.Ankara: TRT Yayınları.

Türkçe'deki Bozulma ve Yabancılaşmanın Araştırılması, Türkçe'nin Korunması ve Etkin Kullanımı için Alınması Gereken Önlemlerin Belirlenmesi Amacıyla Kurulan [10/365] Esas Numaralı Meclis Araştırması Komisyon Raporu.

Üçok, N.(2004). Genel Dilbilim (Lengüistik).İstanbul: Multilingual Yayınları.

Vardar, B.(2011a).Dilbilim Yazıları. İstanbul: Multilingual Yayıncılık.

Vardar, B.(2011b). Dilbilimin Temel Kavram ve İlkeleri.İstanbul: Multilingual Yayıncılık.

Yaman, H.,\& Erdoğan, Y.(2007). Internet Kullanımının Türkçeye Etkileri: Nitel Bir Araştırma.Journal of Language andLinguisticStudies, Cilt:3, Sayı:2.

Yılmaz, M.(...).Internet Ortamında Şekillenen Söyleşi Dili Üzerine Toplum Dil Bilimsel Bir İnceleme. Dede Korkut Dergisi, Cilt: 1, Sayı:1.

Yüksekkaya, G.(2006). Türk Dili Kitabı.İstanbul: Duyap Yayınları.

Zıllığlu, M.(2007). İletişim Nedir?.İstanbul: Cem Yayınevi.

www.ab.org.tr/ab06/bildiri/23.doc.Erişim Tarihi: 20.01.2013.

www.ab.org.tr/ab13/bildiri/206.pdf.Erişim Tarihi: 05.03.2013. 
www.ayk.gov.trErişim Tarihi: 02.04.2013.

www.be.itu.edu.tr/ gulsen.taskin/gulsen_ozturkce.pdf.Erişim Tarihi: 10.11.2012.

www.eksisozluk.com/turkce-40008.Erişim Tarihi: 14.02.2013.

www.tdk.gov.trErişim Tarihi: 24.01.2013.

www.tuik.gov.tr/PreHaberBultenleri.do?id=10880.Erişim Tarihi: 07.02.2013.

www.turkoloji.cu.edu.tr.Erişim Tarihi: 09.02.2013.

www.turkoloji.cu.edu.tr/Genel/18.php.Erişim Tarihi: 09.02.2013.

www.uludagsozluk.com/.Erişim Tarihi: 14.02.2013. 